\title{
MANAGEMENT OF LEADERSHIP EDUCATION OF SANTRI IN PONDOK PESANTREN
}

\author{
Badrud Tamam', Ahmad Farihin² \\ 'University of Wiralodra, Indramayu, Indonesia, 2 Pondok Pesantren Darussalam Kunir, Subang, \\ Indonesia \\ Email: 'ㅁadrud83@gmail.com
}

\begin{abstract}
This research studies about leadership education in Pondok pesantren by focusing on aspects of planning, organizing, actuating, and controlling in the management of leadership education santri. The aims are to obtain a comprehensive description of the implementation of the management functions, including planning, organizing, actuating, and to control in leadership education santri at Pondok pesantren. Qualitative approach used in this study. Interview, observation, and documentation used as data collection tools. The interactive model of data analysis was employed to analyze the data in this study, consisting of three activities: data reduction, data display, and conclusion. The reliability of results obtained with four criteria are credibility, transferability, dependability, and confirmability. The results showed that planning implementation includes the formulation of the program, the establishment of the curriculum, and grouping santri based on the level of maturity of leadership. Organizing involves the division of tasks and the establishment of working groups. Actuating includes training and coaching santri in conducting a leadership training program. Controlling includes reporting and evaluation. Recommendations from the study's findings are all the components should always complement and maintain continuity of santris' leadership education program. Also, organize activities that support the achievement of leadership education programs.
\end{abstract}

\section{Keywords: Leadership Education, Management, Pesantren, Santri}

\section{Introduction}

Santri, as students in pesantren education institutions, are not only required to deepen the religious sciences and master the skills to support life in the future society but also claimed to be the leader of the people who qualified in all aspects. Because to be santri means being a pioneer movement of progress in society, the mandate set out in the vision of the Pondok pesantren. Leadership that exists in every person needs to be sharpened and forged well. Pondok pesantren requires a managerial touch to develop leadership skills in santri.

That is important, given the complexity that will be faced by the santri. In the era of industrial revolution 4.0 at this time, as the result of research committed by Linkedln, there most needed, are leadership, communication, collaboration, and time management (Rif'an, 2019). The answer to it then Pondok pesantren prosecuted for his santri to prepare himself in the form of soft skills, the leadership of course in addition to other skills.
Based on the above facts, it is necessary to research leadership education santri at the Pondok pesantren with emphasis on aspects of management functions, are planning, organizing, actuating, and controlling. This study uses a case study approach to the Pondok pesantren Darussalam Kunir Subang.

This study aimed to obtain and complete and in-depth understanding of leadership education management of santri from the planning, organizing, actuating, and controlling in the Pondok pesantren.

\footnotetext{
Theoretical Review Basic Concepts Of Management

Experts, practitioners, and researcher's management have several views about the definition of management. Here is the definition of management, according to the experts; Rue \& Byars, (2008): Management is a process that involves a guiding or directional group of people toward organizational goals or objectives.
} 
Hersey and Blanchard (2000): Management is a process of how the achievement of organizational objectives through leadership.

Also, Terry (1977)"management is accomplishing predetermined objectives through the efforts of other people. Stoner (1997): Management is a process of planning, organizing, directing, and monitoring efforts of the members of the organization and the other resources so that organizations achieve organizational goals that have been setting. Sudjana (2007): Management is a series of activities undertaken by reasonable persons based on the norms established and, in practice, have a relationship and are intertwined with each other. It was carried out by the person or persons in the organization and given the task to carry out such activities.

Engkoswara \& Komariah Aan (2009) concludes that at least three main focus in defining the management are: A) Management as a capability or expertise that subsequently became the forerunner of management as a profession. Management as a science focusing attention on the skills and managerial abilities classified into abilities or qualifications of technical, human, and conceptual. B) Management as a process that is by doing systematic and integrated management activities. c) Management as art is reflected in the differences in style a person using or empower others to achieve goals.

\section{Functions of Management Planning}

Some experts proposed definition of the planning of a variety of different viewpoints, including Terry, (1977) which states that: "planning is the selection and relating of facts and the making and using of assumption regarding the future in the visualization and formulation of proposed activations believed necessary to achieve desired results."

Furthermore, Hasibuan (2006) reveals the principles of planning as follows: the principle of contribution to objectives, the principle of efficiency of the plan, the principle of primaries of planning, the principle of the pervasiveness of planning, the principle of planning premise and the principle of the policy framework.

\section{Organizing}

Organizing can be understanding as a process of determining, grouping, and setting a wide range of activities required to achieve the goals, put people at each event, providing the necessary tools, establish the authority of a relatively delegated to individuals who will do the activity(Hasibuan, 2006),

Correspondingly, Terry (1977) points out; organizing is the establishment of effective behavioral relationships among persons that they may work together efficiently and gain personal satisfaction in doing tasks selected under given environmental conditions to achieve some goal or objective.

Regarding the process of organizing, can be put forward four pillars of the organization is very important, are the division of labor, grouping the work, determining the relationships among parts of the organization, and the determination of the mechanisms to integrate all activities between parts of the organization or coordination.

\section{Actuating}

Actuating sets all the members of the group to want to achieve and to strike to achieve the objective willingly and keeping with the managerial planning and organizing efforts (Terry, 1977),

Implementation is an effort undertaken to implement the plans and policies that formulated and defined by completing all of the necessary equipment required, where the implementation when to begin and end, and how it is implemented (Gie\& Sutarto, 1997). If the plan realized has been arranged, and if the program of work "achievement-oriented" has formulated, then the next stage is the implementation of the work plan.

The implementation changes the strategic (long-term) plan into a technical (short- term) plan, organizing the resources and the staff, and drawing up rules and procedures;

Giving the task means changing the technical program into a practical plan, and the next destination on the distribution of tasks and resources. 
1) Monitor means that the implementation and progress of the implementation of tasks do not place matters relating to the practical plan. In this case, it is necessary to examine the results achieved.

2) Review means reporting the results of the implementation of activities, analysis of the performance of duties, re-examination and the preparation and subsequent implementation timetable in the report on expected their suggestions and improvements when encountered any difference irregularities (Siagian, 1985),

\section{Controlling}

Controlling is a vetting process of the implementation of all activities of the organization to guarantee that the entire work is doing to correspond to a predetermined plan (Siagian, 1985).

Accordingly, in another view of surveillance, it is understood as the determiner of what has done, meant to evaluate job performance and, if necessary, applying corrective measures action so that the work by a predetermined plan(Terry, 2006).

Meanwhile, according to Murdick, controlling is the basic process remains necessarily required however complicated and breadth of an organization that includes three stages: setting the standard implementation, measurement execution of work compared to the standards, and define gaps/deviation between the implementation of standards and plans(Fattah, 2006),

\section{Leadership Education of Santri in Pondok Pesantren}

In general, the leadership can be defined as the ability and readiness of a person to be able to influence, encourage, persuade, lead, moving, directing, and if necessary, forcing the person or group to receive such influence and then do something that can help to achieve a specific goal which has been setting (Tatty Rosmiyati \& Dedy Ahmad Kurniady, 2009),

In a good Pondok pesantren are modern, and traditional-style would be very easy to find their leadership in the organizational hierarchy. The habit of
Pondok pesantren where leadership will base on one key figure is Kiai. The organizational culture at the Pondok pesantren and all the powers inherent in a Kiai, it involves multiple parties to assist in carrying out the mission of the institution by giving its powers and duties.

Thus, intentional or accidental, in Pondok pesantren leadership education process will happen to anyone who is in it, especially santri.

This study builds upon the assumption that leadership is a necessity that must be owned by anyone, including santri. Santri referred leadership is leadership that can be shaped and refined through a leadership education program hosted by Pondok pesantren through a curriculum that has been setting.

Through santris' educational programs of leadership at the Pondok pesantren with a focus on management functions are planning, organizing, actuating, and controlling is expected to produce students with leadership skills (soft skills) are ideal, so that schools address the challenges of the times. Even ready to produce human beings who are reliable for the future more challenging. In the end, santri who have leadership skills can be a positive influence on society. It can see by meeting the santris' educational goals in the form of educational programs of effective leadership.

\section{Research Method}

This study used a qualitative approach (naturalistic).

The qualitative research used in this research is a case study. This study taking place in Pondok pesantren Darussalam Kunir Subang. To understand the meaning and interpretation of the phenomenon of leadership in Pondok pesantren, it takes involvement and direct appreciation of researchers to the object of study in the field. Therefore, the instrument in this study is the researchers themselves as instruments (human instrument).

Furthermore, this research data collection used three techniques are (1) depth interview, (2) participant 
observation, and (3) study documentation.

Analysis of the data used in this study based on interactive analysis consisting of three grooves interacting and the reduction of the data that classify, direct, dispose of unnecessary, and organize data;

The validity of the data (trustworthiness) is based on the degree of confidence (credibility), transferability, dependability, and certainty, or confirmability (Lincoln \& Guba, 1985).

\section{Findings and Discussion Planning}

Implementation planning in the management of educational leadership at the santri surveyed, based on the results of interviews, showed that planning begins with the formulation of programs, curriculum creation, and grouping students according to the maturity level of leadership.

\section{Program of Leadership Education in Pondok pesantren.}

Based on interviews, the leadership education program of santri divided into two types of programs; The first, santri in the organizational management program that continues to regenerate. In the organization of santri, there are several areas of management of the Education Division, Security Division, Health, and Cleaning Division, Language Division, Sports, Arts, and Talent Development Division. These fields have the committee members and their respective work programs. Through this program, santri nurtured to be the leader according to ability and interest. So that santri received direct guidance of the supervising council organization.

Second, Program of Basic Leadership Training for Santri (BLTS). The program conducted yearly by the organization with the santri to establish a cadre of leadership in an organization successor of santri. The provisions of pesantren like determine participants of the program; has been studying in pesantren at least four years, has finishing specific study program and judged competent to serve as the organization's management. It intended that santri are motivated to improve their ability to organize.

\section{Formation of Santri Leadership Education Curriculum}

Based on interviews with asatidz/teachers council, argued that the curriculum of leadership education santri formed by the board and submitted to Kiai to set. This curriculum can be included in the training program and mentoring program through the organization of santri. In this form of the training program, curriculum materials are provided to participants to add insight about leadership as theories about the primary leadership, organization, conflict management, and organizational psychology. While on organization coaching students, the curriculum included any evaluation meeting management and the development of new administrators at the beginning of the stewardship period.

\section{Grouping students based on the level of leadership maturity}

In addition to class grouping santri by ability and aptitude some learning curriculum, santri are also classified based on the leadership maturity, are; 1) organization member, 2) cadre board, 3) board, 4) assembly supervising organization, and 5) elder member of the organization-each group of santri given different tasks and authority.

Organization member is the santri who are still nurtured by the board. Usually, the santri in this group still needs much guidance to adapt to the culture and environment of pesantren, especially in self-reliance.

Cadre board, Is the santri nurtured to take charge of the organization. In this group of santri to be ready to be fostered by the organization, the committee awarded experience helps administrators' provision and also included in a variety of leadership training.

The Organization board is the santri who given the authority and responsibility to take care of the appropriate organization mandated field. Santri, in this group, guided and supervised a panel of supervising the organization to overcome problems and stints at his management. 
Assembly supervising organizations are santri who have to finish their staff duty during a specific period. Santri, in this group, was given the responsibility of Kiai to guide the organization board in carrying out their mandate.

Eider Member of the organization is the senior santri who has been appointing as chaplain or teacher. Santri, in this group, is often referred to as the cleric by junior students. Because besides, given the task of fostering, organizations are also given the task of teaching.

Based on the above findings can be seen that the implementation of educational planning students at the school leadership has not complied with planning principles as set forth above.

\section{Organizing}

The implementation of organizing educational leadership of santri at studied pesantren, based on interviews with the board of trustees of the organization researchers, noted that the organization of leadership education students include the division of labor, employment grouping, delegation and coordination between divisions. The leadership involved in the education of santri is the teacher/asatidz as supervisor of the organization; senior santri involved in organization supervising assembly and organization management. They were assigned to participate in establishing and run educational programs at the pesantren leadership students. In the broader sense, they were creating an organizational culture where all santri are obliged to follow the leadership level in pesantren.

These findings show that the organization of the educational leadership of santri at the Pondok pesantren who participated had contributed to the fullest because it has met the four critical pillars of the organization covers aspects 1) the division of work, 2) departmentalization, 3) hierarchy and 4) coordination.

\section{Actuating}

Actuating leadership education of santri in Pondok pesantren includes training and coaching students in conducting the leadership training program.

Training and education leadership program of santri implemented in the form of specific programs such as leadership training. While coaching leadership education, students can be implemented in the form of assignments in committee activities of certain events and are also available on the organizational development such as organizational sub-room, classroom organization, and the organization in general santri. All coaching is doing should be reported to all aspects of planning, division of tasks, implementation, and evaluation.

The implementation of leadership education of santri has met a proper procedure because it included detailed planning, division of tasks, monitoring, and review in the form of a report.

\section{Controlling}

Implementation of controlling on leadership education of santri at the Pondok pesantren includes reporting and evaluation.

Based on interviews with the trustees' board, researchers noted that the reporting organization is based on hierarchy and coordination lines that have established, such as the board part reporting their work to the chairman of the board of trustees and continued to be known a panel of tutors.

As for the evaluation of leadership, education programs are routine and spontaneous. It can make the program run properly. The routine evaluation of any duty bearers in this program can arrange to repair periodically to predict the existence of obstacles to be faced. In contrast, spontaneous evaluation of leadership programs can still walk past an unexpected obstacle.

The reporting and evaluation results will bring new measures in the form of policies that lead to improvement and achievement of goals quickly and efficiently.

It can see that the controlling on leadership education program of santri form good reporting and evaluation. It is consistent with the view that the controlling function determiner what has 
done, the intention to evaluate the performance, and, if necessary, apply corrective measures so that the work by a predetermined plan.

\section{Conclusions}

Based on these results, the management leadership education of santri at the Pondok pesantren emphasizes aspects of planning, organizing, actuating, and controlling, the conclusion that the implementation at the Pondok pesantren is not yet fully optimized, there are still some management functions are applied effectively.

Based on the description of the research findings at the studied pesantren, there are some recommendations. It is a form of input for the studied or, in general, Pondok pesantren in efforts produce effective leadership education programs in Pondok pesantren as an effort to graduates of the Pondok pesantren that excellence. Highlighting the leadership program planning implementation, then the trustees of leadership education programs need to pay more attention to the principles of planning a program.

Furthermore, it should be in the preparation and formation of this leadership training program curriculum; program supervisors consult with experts in education, organizational, and other experts to generate better and effective curriculum formulation of santri leadership.

\section{References}

Ahmad Rifa'i Rif'an. (2019). Generasi Emas: 100 Cara Menjaadi Generasi Unggul, Berprestasi, dan Berkontribusi. Jakarta: PT. Elex Media Komputindo.

Engkoswara, \& Aan Komariah. (2009). Administrasi Pendidikan. Bandung: Alfabeta.

Fattah, N. (2006). Landasan Manajemen Pendidikan (8th ed.). Bandung: Remaja Rosdakarya.

Gie, T. L., \& Sutarto. (1997). Pengertian, Kedudukan dan Perincian Ilmu
Administrasi. Yogyakarta: Karya Kencana.

Hersey, P., \& Blanchard, K. H. (2000). Manajemen Perilaku Organisasi: Pendayagunaan Sumber Daya Manusia. Jakarta: Erlangga.

James F. Stoner. (1997). Manajemen. Surabaya: Erlangga.

John R. Creswell. (2010). Research Design: Pendekatan Kualitatif, Kuantitatif, dan Mixed. Yogyakarta: Pustaka Pelajar.

Lincoln, Y. S. \& Guba., E. G. (1985). Naturalistic Inquiry. Beverly Hills California: SAGE Publication.

Malayu S.P Hasibuan. (2006). Manajemen: Dasar, Pengertian dan Masalah. Jakarta: Bumi Aksara.

Miles, M. B., \& A.M. Huberman. (1994). Qualitative Data Analysis: an Expanded Sourcebook (2nd ed.). Thousand Oaks California: SAGE Publication Inc.

Rue, L. W., \& Byars, LI. L. (2008). Management: Skills and Application. McGraw Hill Education.

Siagian, S. P. (1985). Filsafat Administrasi. Jakarta: Gunung Agung.

Sudjana. (2007). Sistem dan Manajemen Pelatihan: Teori dan Aplikasi. Bandung: Falah.

Tatty Rosmiyati, \& Dedy Achmad Kurniady. (2009). Kepemimpinan Pendidikan. Bandung: Alfabeta.

Terry, G. R. (1977). Principle of Management. Illinois: Richard D. Irwin.

Terry, G. R. (2006). Prindip-Prinsip Manajemen. Jakarta: Bumi Aksara. 